Nig. J. Biotech. Vol. 35 (2018) 93-98

ISSN: 01891731

Available online at

http://www.ajol.info/index.php/njb/index

and www.biotechsocietynigeria.org

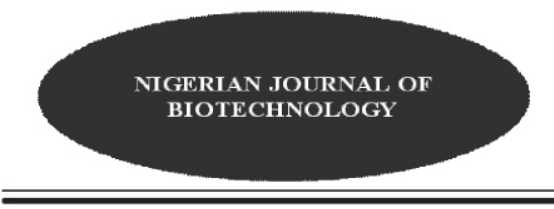

DOI: https://dx.doi.org/10.4314/njb.v35i1.11

\title{
Controlling Microbial Contamination and Browning of Coconut (Cocos nucifera L.) Inflorescence Culture
}

${ }^{*}$ Nwite, A. P $^{1,2}$., Owoh, N. B. ${ }^{1,2}$, Emoghene, B. O. ${ }^{1}$, Isalar, C. E. ${ }^{1,2}$ and Shittu, H. O. ${ }^{2}$

${ }^{1}$ Physiology Division, Nigeria Institute for Oil Palm Research (NIFOR), Benin City, Nigeria.

${ }^{2}$ Department of Plant Biology and Biotechnology, University of Benin, Benin City, Nigeria

Copyright resides with the authors in terms of the Creative Commons License 4.0.
(See http://creativecommons.org/licenses/by/4.0/).
Condition of use: The user may copy, distribute, transmit and adapt the work, but must recognize
the authors and the Nigerian Journal of Biotechnology.

Abstract

Surface contamination of explants and culture browning are major problems associated with in vitro culture procedures. The study was aimed at investigating the effect of different sterilizing agents in controlling microbial contamination and browning in coconut (Cocos nucifera $L$ ) inflorescence culture. Eeuwens medium, supplemented with 2,4-Dichlorophenoxyacetic acid (2,4-D) at concentration $40 \mathrm{mg} / \mathrm{I}$ and 6-Benzyl amino purine (BAP) at concentration $1 \mathrm{mg} / \mathrm{I}$ was used for the experiment. Immature coconut inflorescences with intact inner spathes were used as explants. The explants were sterilized with different sterilizing agents: mercuric chloride $\left(\mathrm{HgCl}_{2}\right)$, sodium hypochlorite $(\mathrm{NaClO})$, silver nitrate $\left(\mathrm{AgNO}_{3}\right)$ and calcium hypochlorite $\left(\mathrm{Ca}(\mathrm{ClO})_{2}\right)$, each at concentrations $0.1,0.2,0.3$ and $0.4 \%$ for 5 min sterilization time. This was followed by rinsing the explants with distilled water four successive times and were inoculated on Eeuwens medium. Percentage culture contamination and level of browning were recorded on weekly basis for four weeks. The results obtained showed that contamination was less in the cultures, whose explants were sterilized with $\mathbf{H g C l}_{2}$ and $\mathrm{AgNO}_{3}$, but the level of culture browning was higher, four weeks after culture initiation when $\mathrm{HgCl}_{2}$ was used for sterilization. By a way of comparison, $\mathrm{AgNO}_{3}$ at concentrations between $0.1-0.3 \%$ were most effective and to be preferred for sterilizing coconut inflorescence in controlling culture contamination and browning. It is therefore recommended that contamination and browning in coconut inflorescence cultures can be controlled by the use of $\mathrm{AgNO}_{3}$ at concentrations between $0.1-0.3$.

Keywords: Cocos nucifera, Immature inflorescence, Sterilizing agents, Contamination and Browning

*Correspondence author: peacekaino@gmail.com; 08062919144

\section{INTRODUCTION}

In the tropical Pacific islands, coconut (Cocos nucifera) palms play an important roles in the culture, tourism, agriculture and environment. Coconut is a palm that is grown all over the world in about 12.2 million ha of land, of which $88 \%$ of these are located in the Asia Pacific region (Warth, 1933). There are more than 86 countries on four continents where coconut palm is grown (Thangaraj and Muthuswani, 1990). In the tropics, the coconut plant has the largest number of uses. The plant parts are used for food, oil production, as construction material, source of energy, and cosmetics (Warner et al., 2007). Coconut cultivars are generally classified into the Tall and Dwarf types. Most of the dwarf cultivars are used in genetic improvement programs (Bourdeix et al., 2005). However, the dwarf cultivar of coconut is faced with several challenges from drastic production constraints, which include pests and diseases. 
In addition, several aging coconut plantations are now being uprooted in order to make way for the planting of new once (Warner et al., 2007). Therefore, these challenges have necessitated the need to implement efficient coconut germplasm via in vitro technique of tissue culture that allows germination and conversion into plantlets in a controlled environment.

Many research works have been done in order to propagate Coconut from different types of explants such as immature embryos, anthers, and tender leaves (Branton and Blank, 1984). In the present study, immature inflorescence was used as the explant for in vitro culture establishment. One of the greatest problems associated with micropropagation procedure is contamination with fungi and bacteria. Therefore, an aseptic environments are essential for successful tissue culture procedures. To maintain a sterile condition, all culture vessels, media and instruments used in handling tissues must be sterilized (Goswami and Handiqu, 2013). Sterilization is the process where by explants are made contamination free before in vitro cultures are established. Several sterilization agents are used to decontaminate tissues during sterilization and should be carried out in such a way that the plant materials will not lose their biological activity. Therefore, explants are surface sterilized only by treatment with disinfectant solution at suitable concentrations for a specified period (Kumar et al., 2000). Apart from contamination, another major problem in in vitro cultures of coconut inflorescence is phenolization. This term is described as the blackening and browning of explants shortly after inoculation. It is caused by the release of phenolic compounds into the media where they are immediately oxidized by peroxidases (ElShafey et al., 1999). The objective of this study was to investigate the effectiveness of four sterilizing agents (mercuric chloride, sodium hypochlorite, silver nitrate and calcium hypochlorite) in controlling contamination and reduction of tissue browning of coconut in vitro.

\section{Materials and Methods}

Source of Explants

Immature coconut inflorescences used for this study were obtained from the Dwarf Green coconut palms in Anglican Church field,
Nigerian Institute for Oil Palm Research (NIFOR), Benin City. The explants were collected from the leaf axil frond, as described by Rillo, (1989) for oil palm. After collection of explants, it was wrapped in aluminum foil and then taken to the laboratory for analysis.

\section{Preparation of Culture Medium}

The basal medium used for this experiment was the formulation of Eeuwens (Eeuwens, 1976). The medium contained 35g/l sucrose and $2.5 \mathrm{~g} / \mathrm{l}$ activated charcoal and was supplemented with 2,4-Dichlorophenoxyacetic acid (2,4-D) at concentration $40 \mathrm{mg} / \mathrm{l}$ and 6Benzyl amino purine (BAP) at concentration 1 $\mathrm{mg} / \mathrm{l}$ for morphological responses. The $\mathrm{pH}$ of the medium was adjusted to 5.7 and solidified with 7 $\mathrm{g} / \mathrm{l}$ agar. The medium was autoclaved at $121^{\circ} \mathrm{C}$ for $20 \mathrm{~min}$.

\section{Sterilization of Explants}

In order to investigate the effectiveness of the four different sterilizing agents in controlling microbial contamination, mercuric chloride, sodium hypochlorite, silver nitrate and calcium hypochlorite, each at $0.1 \%-0.4 \%$ were used for sterilizing coconut inflorescence. The explants were washed with detergent and rinsed repeatedly with running tap water for $10-15 \mathrm{~min}$, before external spathes were removed under aseptic conditions. The inflorescences with the intact inner spathes were then introduced into the various sterilizing agents for $5 \mathrm{~min}$, with continuous stirring. The disinfectant solution was then discarded and the explants were rinsed four successive times with sterile distilled water to avoid cytotoxic effect.

Inoculation of Explants and Incubation of Cultures

The sterilized explants were inoculated into the culture medium. The initiated cultures were incubated in the growth room at $25 \pm 2^{\circ} \mathrm{C}$ (in the dark). Cultures were maintained in the dark during the first 4 weeks for observations and data on percentage contaminated culture and level of culture browning were recorded on weekly basis for four weeks.

\section{Results}

The results obtained one week after culture initiation, when different sterilizing 
agents were used to sterilize coconut inflorescence explants in controlling culture microbial contamination and browning are presented in Table 1 . There was no microbial contamination observed in the cultures whose explants were sterilized with $\mathrm{HgCl}_{2}(0.1 \%$ and $0.4 \%$ concentrations), $\mathrm{AgNO}_{3}(0.1 \%, 0.2 \%$ and $0.4 \%$ concentrations $), \mathrm{Ca}(\mathrm{ClO})_{2}(0.1 \%$ concentration) and $\mathrm{NaClO}(0.2 \%$ and $0.4 \%$ concentrations). There was no browning observed in all the cultures. Two weeks after culture initiation, the results (Table 2) obtained indicated that most of the cultures were contaminated, except the cultures whose explants were sterilized with $\mathrm{HgCl}_{2} \quad(0.4 \%$ concentration) and $\mathrm{AgNO}_{3}(0.1,0.2$ and $0.4 \%$ concentrations). At this stage, slight browning was observed in cultures whose explants were sterilized with concentrations of 0.3 and $0.4 \%$ of $\mathrm{HgCl}_{2 ;} 0.4 \%$ of $\mathrm{AgNO}_{3}$ and $0.4 \%$ of $\mathrm{Ca}(\mathrm{ClO})_{2}$. There was no single browning in cultures whose explants were disinfected with $\mathrm{NaClO}$ at all

Table 1: Effect of different sterilizing agents in controlling microbial contamination and browning in coconut inflorescence culture, one week after initiation

\begin{tabular}{lccc}
\hline \multicolumn{1}{c}{ Sterilizing agent } & $\begin{array}{c}\text { Concentration of } \\
\text { sterilizing agent (\%) }\end{array}$ & $\begin{array}{c}\text { \% contaminated } \\
\text { culture }\end{array}$ & $\begin{array}{c}\text { Level of culture } \\
\text { browning }\end{array}$ \\
$\mathrm{HgCl}_{2}$ & 0.1 & 0.00 & - \\
& 0.2 & 6.7 & - \\
& 0.3 & 6.7 & - \\
$\mathrm{AgNO}_{3}$ & 0.4 & 0.0 & - \\
& 0.1 & 0.0 & - \\
& 0.2 & 0.0 & - \\
$\mathrm{Ca}(\mathrm{ClO})_{2}$ & 0.3 & 6.7 & - \\
& 0.4 & 0.0 & - \\
& 0.1 & 13.3 & - \\
$\mathrm{NaClO}$ & 0.2 & 6.7 & - \\
& 0.3 & 6.7 & - \\
& 0.4 & 0.0 & - \\
$-:$ No browning & 0.1 & 13.3 & - \\
\end{tabular}

Table 2:Effect of different sterilizing agents in controlling microbial contamination and browning in coconut inflorescence culture, two weeks after initiation .

$\begin{array}{cr}\text { Sterilizing agent } & \begin{array}{c}\text { Concentra } \\ \text { sterilizing a }\end{array} \\ & 0.1 \\ \mathrm{gCl}_{2} & 0.2 \\ & 0.3 \\ & 0.4 \\ \mathrm{gNO}_{3} & 0.1 \\ & 0.2 \\ & 0.3 \\ \mathrm{Ca}(\mathrm{ClO})_{2} & 0.4 \\ & 0.1 \\ & 0.2 \\ \mathrm{NaClO} & 0.3 \\ & 0.4 \\ & 0.1 \\ & 0.2 \\ & 0.3 \\ & 0.4\end{array}$

-: No browning; +: Slight browning

$\%$ contaminated
culture

13.3

6.7

6.7

0.0

0.0

0.0

6.7

0.0

20.0

13.3

20.0

6.7

13.3

13.3

13.3

6.7
Level of culture browning 
Table 3 presents the results obtained for microbial contamination and culture browning, three weeks after culture initiation. The level of culture contamination increased, but there was no contamination observed in cultures whose explants were sterilized with $\mathrm{HgCl}_{2}(0.4 \%$ concentration) and $\mathrm{AgNO}_{3}(0.1$ and $0.4 \%$ concentrations $)$, but the level of culture browning increased. There was no culture browning observed in cultures sterilized with $0.1 \%$ $\mathrm{AgNO}_{3}$. By the fourth week after culture initiation, only cultures whose explants were sterilized with $0.1 \%$ $\mathrm{AgNO}_{3}$ were observed not to have been contaminated and there was also no culture browning (Table 4).

Table 3: Effect of different sterilizing agents in controlling microbial contamination and browning in coconut inflorescence culture, three weeks after initiation

\begin{tabular}{cccc}
\hline \multicolumn{1}{c}{ Sterilizing agent } & $\begin{array}{c}\text { Concentration of } \\
\text { sterilizing agent } \\
(\%)\end{array}$ & \% contaminated culture & $\begin{array}{c}\text { Level of culture } \\
\text { browning }\end{array}$ \\
$\mathrm{HgCl}_{2}$ & 0.1 & 20.0 & + \\
& 0.2 & 6.7 & + \\
& 0.3 & 6.7 & + \\
$\mathrm{AgNO}_{3}$ & 0.4 & 0.0 & + \\
& 0.1 & 0.0 & - \\
& 0.2 & 6.7 & - \\
$\mathrm{Ca}(\mathrm{ClO})_{2}$ & 0.3 & 13.3 & + \\
& 0.4 & 0.0 & - \\
& 0.1 & 33.3 & + \\
$\mathrm{NaClO}$ & 0.2 & 13.3 & + \\
& 0.3 & 33.3 & + \\
& 0.4 & 13.3 & + \\
& 0.1 & 33.3 & + \\
& 0.2 & 20.0 & +
\end{tabular}

-: No browning; +: Slight browning

Table 4: Effect of different sterilizing agents in controlling microbial contamination and browning in coconut inflorescence culture, four weeks after initiation

\begin{tabular}{lccc}
\multicolumn{2}{c}{$\begin{array}{c}\text { browning in coconut inflorescence culture, four weeks after initiation } \\
\text { Concentration of } \\
\text { Sterilizing agent }\end{array}$} & $\begin{array}{c}\text { \% contaminated } \\
\text { culture }\end{array}$ & $\begin{array}{c}\text { Level of culture } \\
\text { browning }\end{array}$ \\
\hline $\mathrm{HgCl}_{2}$ & 0.1 & 20.0 & ++ \\
& 0.2 & 13.3 & ++ \\
& 0.3 & 6.7 & ++ \\
$\mathrm{AgNO}_{3}$ & 0.4 & 0.0 & ++ \\
& 0.1 & 0.0 & - \\
& 0.2 & 6.7 & - \\
$\mathrm{Ca}(\mathrm{ClO}) 2$ & 0.3 & 13.3 & + \\
& 0.4 & 6.7 & + \\
& 0.1 & 40.0 & + \\
$\mathrm{NaClO}$ & 0.2 & 20.0 & + \\
& 0.3 & 33.3 & + \\
& 0.4 & 13.3 & + \\
& 0.1 & 26.7 & + \\
& 0.2 & 20.0 & +
\end{tabular}

-: No browning; +: Slight brown; ++: Dark brown 


\section{Discussion}

Media used for in vitro cultures also support growth of microorganisms, especially bacteria and fungi, which have higher proliferating capability than plant cells, hence there is great need for surface sterilization of explants. The effectiveness of tissue sterilization depends on certain factors which include explant source, age, plant part and contamination levels of explants (Firoz et al., 2016).

Microbial contamination (13.3\%) was first observed in cultures whose explants were sterilized with sodium hypochlorite $(0.1 \%$ concentration), four days after culture initiation. Contamination was later observed in some of the other cultures within the first week. This observation was similar with Hadiuzzaman et al. (2001), who reported that contamination was observed in banana shoot tip culture, 5 days after inoculation of explants. All the sterilizing agents at various concentrations were able to provide basal control measure of reducing microbial contamination, one week after inoculation.

In the present study, among the sterilizing agents tested, $0.1 \%$ silver nitrate seemed to be the best in controlling microbal contamination in coconut inflorescence cultures. There was no any contamination recorded in cultures whose explants were sterilized with $0.1 \%$ silver nitrate throughout the study period (Tables 1-4). A similar observation of the effectiveness of silver nitrate in reducing culture microbial contamination was made by Osterc et al. (2004), who reported a reduction in culture contamination rate when $1 \%$ silver nitrate was used to sterilize sour cherry shoot plant. Mercuric chloride also proved to be effective next to silver nitrate. For the first three weeks (Tables 1-3), microbial contamination was not observed in the cultures who explants were sterilized with mercuric chloride, except in the fourth week, where $6.7 \%$ contamination rate was recorded (Table 4). A similar observation by Sushamakumari (2000) reported the use of $0.1 \%-0.2 \%$ mercuric chloride for surface sterilization of immature inflorescence explants of Hevea. Other researchers such as Oyebanji et al. (2009) have also reported sodium hypochlorite to be a very effective killer of bacteria and fungi, but in the present study, the use of sodium hypochlorite was not effective for the surface sterilization of coconut inflorescence.

Apart from microbial contamination, another major problem in coconut tissue culture is the browning of culture shortly after inoculation. The results obtained in this study (Tables 1 and 2) indicated that all the tested sterilizing agents were able to control browning for the first two weeks of culture initiation. Slight browning was observed after two weeks of culture initiation in cultures whose explants were sterilized with mercuric chloride $(0.3 \%$ and $0.4 \%$ concentrations), silver nitrate ( $0.4 \%$ conc.) and calcium hypochlorite ( $0.4 \%$ conc.). Also, silver nitrate $(0.1 \%)$ seemed to be most effective in controlling culture browning. A similar report has been made in solving the problem of browning on date palm inflorescence explants (El-Shafey et al., 1999).

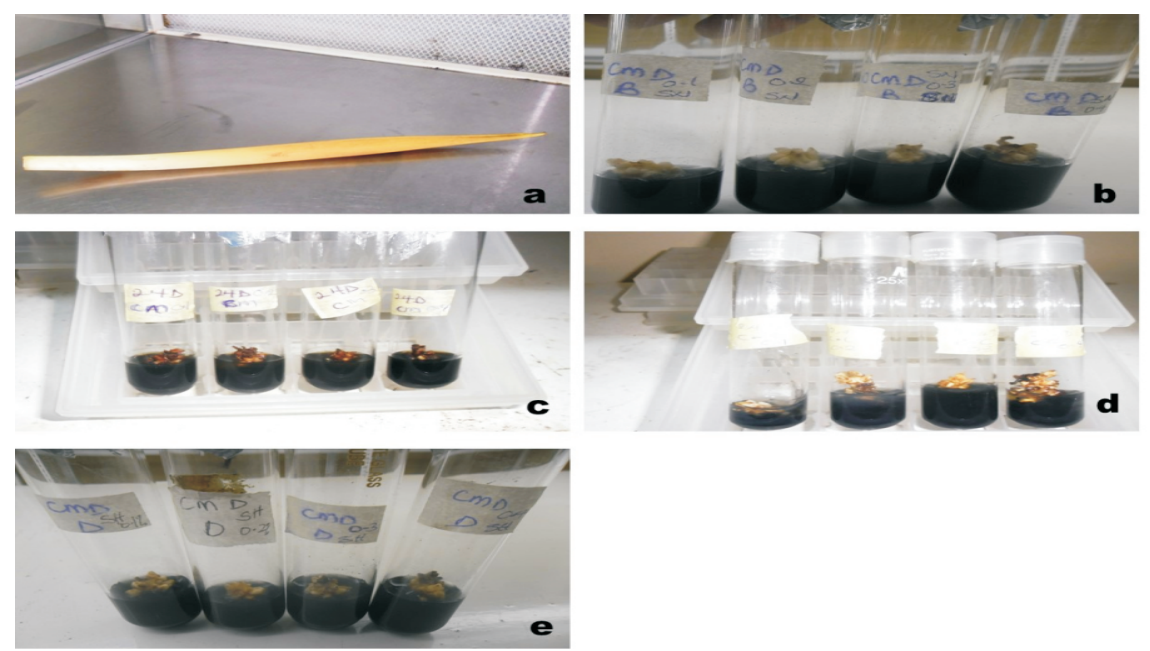

Plate 1: Culture establishment using different sterilizing agents on coconut inflorescence explants. a: Immature coconut inflorescence explant; Cultures established four weeks post inoculation using: b) Silver nitrate; c) Mercury chloride; d) Calcium hypo chlorite) Sodium hypo chlorite, sterilizing agents 


\section{Conclusion}

From the results obtained in this study, all the tested sterilizing agents (mercuric chloride, sodium hypochlorite, silver nitrate and calcium hypochlorite) offered basal level control of microbial contamination and culture browning when used for sterilizing coconut explants. By a way of comparison, the use of $0.1 \% \mathrm{AgNO}_{3}$ seemed to be most effective in controlling microbial contamination and culture browning in coconut inflorescence.

\section{Acknowledgements}

The authors wish to sincerely thank $\mathrm{Mr}$ Idaba Owoicho, a laboratory scientist of the Physiology Division, Nigeria Institute for Oil Palm Research (NIFOR), Benin City, Nigeria for his technical assistance throughout the study.

\section{References}

Bourdeix, R., Konan, J. L. and Cho, P. N. (2005). Coconut: $A$ guide to traditional and improved varieties. Editions, Diversiflora Montpellies. France. p.94.

Branton, R. L. and Blake, J. (1984). Clonal propagation of coconut. Palm. In: E pushparajah and CP soon, eds. Cocoa and coconuts: Progress and Outlook, Kuala Lumpur. Incor. Soc. Plant. 77: $1-780$.

Eeuwens, C. J. (1976). Mineral requirements for growth and callus initiation of tissue explants excised from mature coconut palms (Cocos nucifera) and cultured in vitro. Phy. Plant. 36: 2328.

El-Shafey, Y. E., Nesiem, M., Habib, M. and Abdel, M. (1999). Browning phenomenon: A serious problem in date palm tissue culture. J. Agric. Sci. 11: $78-87$.

Firoz, A. M., Ekhlas U. M., Ruhul A., Abdur, M. R., Manik, M. A. and and Khatun, M. M. (2016). Studies on the effect of various sterilization procedure for in vitro seed germination and successful micropropagation of Cucumis sativus. Inter. J. Pure App. Bio. 4(1): 75-81.

Goswami, N. and Handique, P. (2013). In Vitro Sterilization Protocol for Micropropagation.
Indian J. Appl. Res. 51: 21 - 28.

Hadiuzzaman, S. U., Habiba, S., Reza, M., Saha, L. and Khan, M. R. (2001). Development of a sustainable protocol for contamination free culture of table bananas and identification of associated endogenous bacteria. In: 4th Int. Plant Tissue Culture Conference, Dhaka, Bangladesh. Abstracts, pp: 24.

Kumar, P. G., Pua, S., and Chi, M. A. (2000). Influence of silver nitrate in in vitro culture of Decalepic hamiltonii plant. Biddington, 14: 32 41.

Osterc, G., Luthar, Z., Štampar, F. (2004): The importance of sterilization procedure for producing vigorous cherry plants (Prunus sp.) in vitro. Acta Agric. Slov. 83:45 - 51.

Oyebanji, B., Nweke, O., Odebunmi, O., Galadima, B., Idris, S. and Nnodi, N. (2009). Simple, effective and economical explantsurface. Afr. J. Biot. 12: 53 - 96.

Rillo, E. P. (1989). A non destructive technique for collecting immature inflorescences for tissue culture. Phili. J. Coco. Stud 14:16 - 17

Thangaraj, T. and Muthuswani, S. (1990). Coconut in T.K. Bose andMira, S. K. (eds) fruits. Tropical and subtropical Naya Prokash Calcutta $335-385$.

Warner, B., Quirke, D. and Longmore, C. (2007). A review of the future prospects for the world coconut industry and past research in coconut production and product. ACIAR, Canberra, Australia

Warth, E. (1933). Distribution, origin and cultivation of the coconut palm. Ber Deut. Bot. 51: $301-304$

Sushamakumari, R. E. (2000). A decontamination procedure for in vitro culture of inflorescence explants of Hevea. Acta Hort. 21: $33-42$. 